\title{
Risk of Heavy Metals Accumulation in Agricultural Lands by Treated Wastewater as Source of Irrigation in the Province of Batna (East Algeria)
}

\author{
Malika Chichoune ${ }^{1, *}$, Nouari Souiher ${ }^{1}$, and Belkacem Messaid ${ }^{2}$ \\ ${ }^{1}$ Department of Geography and Territorial Planning, Houari Boumediene Sciences and Technology University, Algeria \\ ${ }^{2}$ Department of Hydraulics, Batna 2 University, Algeria
}

${ }^{*}$ Corresponding author: Malika Chichoune, Department of Geography and Territorial Planning, Houari Boumediene Sciences and Technology University, Algeria, E-mail: malikamiky@yahoo.fr

Received: 24 Feb, 2020 | Accepted: 17 Mar, 2020 | Published: 20 Mar, 2020

Citation: Chichoune M, Souiher N, Messaid B (2020) Risk of Heavy Metals Accumulation in Agricultural Lands by Treated Wastewater as Source of Irrigation in the Province of Batna (East Algeria). Int J Water Wastewater Treat 6(1): dx.doi.org/10.16966/2381-5299.165

Copyright: (c) 2020 Chichoune $\mathrm{M}$, et al. This is an open-access article distributed under the terms of the Creative Commons Attribution License, which permits unrestricted use, distribution, and reproduction in any medium, provided the original author and source are credited.

\begin{abstract}
The presence of heavy metals in treated wastewater has considered a serious environmental problem in many countries such as Algeria, where the wastewater irrigation has become a widespread practice. In this study, we were interested in toxic metals such as copper (Cu), chromium (Cr), lead $(\mathrm{Pb})$ and cadmium $(\mathrm{Cd})$ in wastewater, and treated wastewater and the possible risk or danger they can cause to human health and animals in the region of Batna and Timgad. Wastewater samples for $\mathrm{Cu}, \mathrm{Cr}, \mathrm{Pb}$ and $\mathrm{Cd}$ concentrations were analyzed.

The trend of heavy metal concentrations in Batna, Fesdis and Djerma samples was $\mathrm{Pb}>\mathrm{Cr}>\mathrm{Cd}>\mathrm{Cu}$. Yet concentrations for $\mathrm{Cr} 0.31-0.60 \mathrm{mg} / \mathrm{l}$ and $\mathrm{Cd}$ $0.08-0.23 \mathrm{mg} / \mathrm{l}$ exceeded the permissible limits. Our results revealed certain risks for the region of Fesdis and Djerma. Thus, preventive measures must be taken to reduce heavy metal pollution of treated wastewater to preserve agricultural lands and protecting both, human and animal health in the province of Batna.
\end{abstract}

Keywords: Wastewater; Heavy metals; Irrigation; Risk; Preserve

\section{Introduction}

The wilaya of Batna, is facing a growing demand for water, the limitation of natural resources and their depletion due to climate change. The considerable potential of raw wastewater can provide a good alternative for a variety of uses, such as irrigation and industrial activities. The ambitious goal of reusing thousands of cubic metres by 2030 can only be achieved by changing the current model. It is a question of moving to the "treatment and reuse" approach instead of the "treatment and discharge" approach.

The reuse of wastewater in agriculture has become a widespread practice in regions where water deficits are most pronounced [1]. In general, this resource contains substantial amounts of beneficial nutrients and toxic pollutants, which are creating opportunities and problems for agricultural production, respectively [2]. Therefore, long-term use of industrial or municipal wastewater in irrigation may lead to the accumulation of heavy metals in agricultural soils and plants [3]. The use of wastewater or polluted water in general, poses risks to human health since it may contain excreta-associated pathogens (viruses, bacteria, protozoan and multicellular parasites), skin irritants and toxic chemicals such as heavy metals, pesticides and pesticide residues. When wastewater is used in agriculture, pathogens and certain chemicals are the main hazards to human health through different pathways [4]. The metals that may be present in wastewater, Cadmium (Cd), Copper (Cu), Molybdenum (Mo), Nickel (Ni) And Zinc $(\mathrm{Zn})$, can constitute a significant health risk for humans and animals and can also affect, in the long term, irrigated crops as a result of accumulation in the soil [5]. Irrigation with heavy metal contaminated water can deteriorate the quality of soil as well as the agricultural produce [6]. The main objectives of this study are primarily to quantify the concentration of these heavy metals $(\mathrm{Cr}, \mathrm{Cu}$, $\mathrm{Pb}$ and $\mathrm{Cd}$ ) in irrigation wastewater; to see which lands of Batna and Timgad are far from the risk heavy metals contamination.

\section{Materials and Methods}

\section{Study area}

The current study was carried during autumn 2017 in two regions of the province of Batna.

The city of Batna has a wastewater treatment plant (WWTP) with a capacity of 200000 of population equivalents. Batna WWTP is located on a surface area of 12 ha and is located in the north of the city. It is bounded to the north by Oued El Ghorzi, to the east by Oued El Ghorzi and a high-pressure gas pipeline, to the west by Oued El 
Ghorzi and a high-voltage power line, and to the south by a private farm.

The city of Timgad has a wastewater treatment plant (WWTP) with a capacity of 13800 of population equivalents. Timgad WWTP is located on a surface area of 10 ha and is located in north of the city of Timgad. It is bounded to the north by agricultural land (private farm), to the east by agricultural land (private farm), to the west by agricultural land (private farm) and to the south by Oued Soultz.

\section{Sampling of wastewater}

Samples were taken from the water intakes at targeted representative locations, which generally consisted of sampling at locations where contaminants were suspected to be present. Sampling was done at four different locations for each wastewater treatment plant.

Raising for the Banta wastewater treatment plant (WWTP): First point: Before entering the Batna wastewater treatment plant where the water is only discharges are industrial and household discharges plus discharges imported by the rainwater in other words wastewater before being treated by the wastewater plant.

-Second point: Just after the Batna purification plant at the point of driving the water purified to the Oued Ghourzi, just after treating wastewater.

-Third point: At the city of Fessdis, from a canal of Oued Ghourzi that crosses the city.

-Fourth point: At the city of Djerma from a canal of Oued Ghourzi that crosses cultural fields of the city (Figure 1).
Raising for the Timgad wastewater treatment plant (WWTP): First point: Before entering the Timgad WWTP where the water is still untreated; where the discharges are household discharges plus discharges brought by the water before it arrives to the wastewater plant of Timgad.

-Second point: Just after the Timgad wastewater treatment plant the exit of treated wastewater.

-Third point: Private farm crossed by a canal of Oued Reboaa.

-Fourth point: Canal of Oued Reboaa just before the Koudiet Lemdouar dam (Figure 2).

Water withdrawals were determined according to the experimental protocol described by Rodier J [7]. The latter consists in taking water in the middle of the wadi bed in full flow at a depth of about $50 \mathrm{~cm}$ or at mid-depth if the water height is low (less than $50 \mathrm{~cm}$ ). Sampling must also be carried out away from banks and natural or artificial obstacles, outside dead zones and eddies, while avoiding the resuspension of deposits.

\section{Sampling analysis}

The water samples were collected along the two study areas as mentioned in the two figures. Samples of 2 liters were stored in polyethylene bottles, pre-washed with nitric acid (1\%) and stored $4^{\circ} \mathrm{C}$ until analysis is done. Then, $\mathrm{pH}$ and heavy metals concentrations were concentrations were measured according to standard methods [8]. The total metal concentration of $\mathrm{Cd}, \mathrm{Cu}, \mathrm{Cr}, \mathrm{Pb}$ in the filtered and digestive samples are determined in $\mathrm{mg} / \mathrm{L}$ by using Atomic Absorption Spectrophotometer (AAS, Shimadzu AA-6300). Analysis was carried

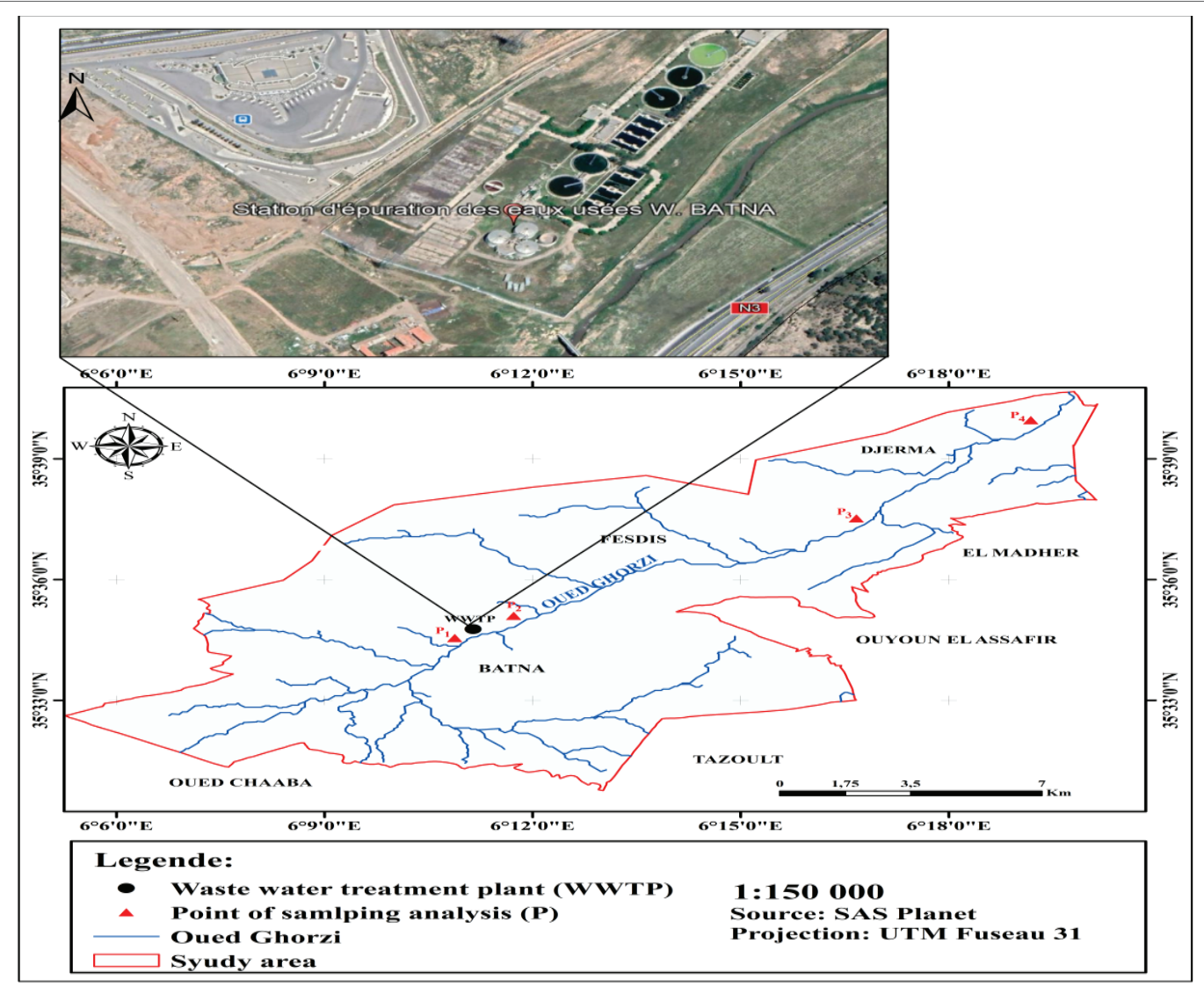

Figure 1: Study area of Batna WWTP. 


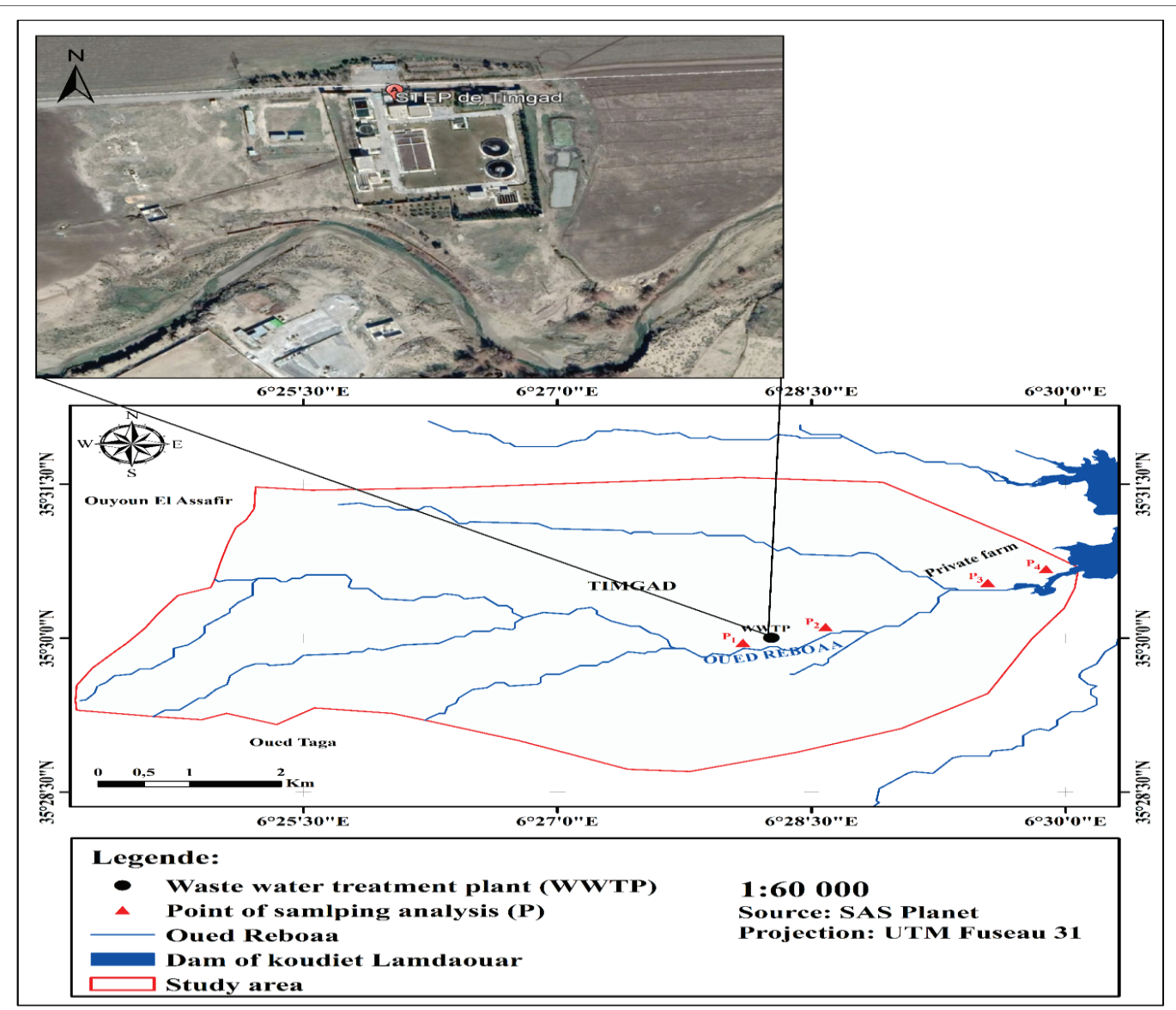

Figure 2: Study area of Timgad WWTP.

out in triplicate and average values are reported. The AAS was calibrated with relevant Shimadzu AAS spectroscopic grade standards. Flame atomic absorption spectrophotometer (Shimadzu double beam Atomic Absorption Spectrophotometer).

\section{Results and Discussion}

All of the water samples tend toward being alkaline, with pHs ranging from 7.41 to 7.68 and this for the Batna Feisdis Djerma samples. Timgads pHs samples also were ranging from 7.70 to 7.74 (Table1) with (Figures 3 and 4).

The mean heavy metal concentrations $(\mathrm{mg} / \mathrm{l})$ in wastewater and treated wastewater between the sites of Batna were 0.08-0.23 for Cd, $0.40-0.73$ for $\mathrm{Pb}, 0.31-0.60$ for $\mathrm{Cr}$ and $0.138-0.155$ for $\mathrm{Cu}$ (Table 2) and (Figure 5). The concentrations of heavy metals in wastewater channel were highest relatively for the $\mathrm{Pb}$, followed by $\mathrm{Cr}, \mathrm{Cd}$, and $\mathrm{Cu}$. Concentrations of $\mathrm{Cu}$ and $\mathrm{Pb}$ in the wastewater were below the permissible limits of heavy metals allowed in the irrigation water, but $\mathrm{Cd}$ and $\mathrm{Cr}$ exceeded the limit set by FAO/WHO (Table 3); Due to the activities of the industrial sector of the city of Batna (a variety of industrial activities including: Tanneries, Batteries, milk, Textile, etc.) where these factories do not have internal plants for the recycling of their industrial wastewater, which is discharged without treatment and directly into Oued El Ghourzi and the Batna WWTP. The heavy metals that are toxic to humans are $\mathrm{Pb}, \mathrm{Cd}$ and $\mathrm{Cr}$. The toxicity of lead and its clinical manifestations have been known for a long time (lead poisoning). In recent years, an increasing number of studies have highlighted the danger of lead ingestion even at very low doses, especially for children [9]. Cadmium is the subject of particular attention because of its prolonged persistence and high toxicity to many living organisms even at very low concentrations $[10,11]$. The fate of heavy metals depends on many factors, including the nature of the soil and its acidity; in acidic and humus-poor soils of low mechanical composition, heavy metals do not accumulate [12].

Timgad's samples have recorded acceptable values for the metals tested, all of which were below standard for all sampling points. $\mathrm{Pb} 0.1$ $\mathrm{mg} / \mathrm{l}-0.3 \mathrm{mg} / \mathrm{l}, \mathrm{Cr} 0.14 \mathrm{mg} / \mathrm{l}-0.4 \mathrm{mg} / \mathrm{l}$, while Cd is less than $0.05 \mathrm{mg} / \mathrm{l}$ (Table 4, Figure 6). Depleted of industrial units, the city of Timgad is almost far from any contamination with heavy metals, in spite of this, remains the urban wastewater which involves intensive control before and after its treatment in the Timgad WWTP because it is discharged into the Oued Reboaa which feeds the Koudiet Lemdouar Dam.

The Fesdis, Djerma and Timgad regions are agricultural and cattle breeding regions, especially Djerma and El Maadar (first milk producer in the province of Batna). Irrigation with wastewater, which has been practiced for years in some agricultural areas of the Batna region, is said to be at the origin of part of the agricultural activity in a semi-arid region that has been experiencing chronic drought in recent years due to climate change. The partially treated wastewater from Oued El Gourzi is used to irrigate 1073 ha of agricultural land in the communes of Fisdis (250 ha), El Madher (160 ha) and Djerma (600 ha) [13]. 


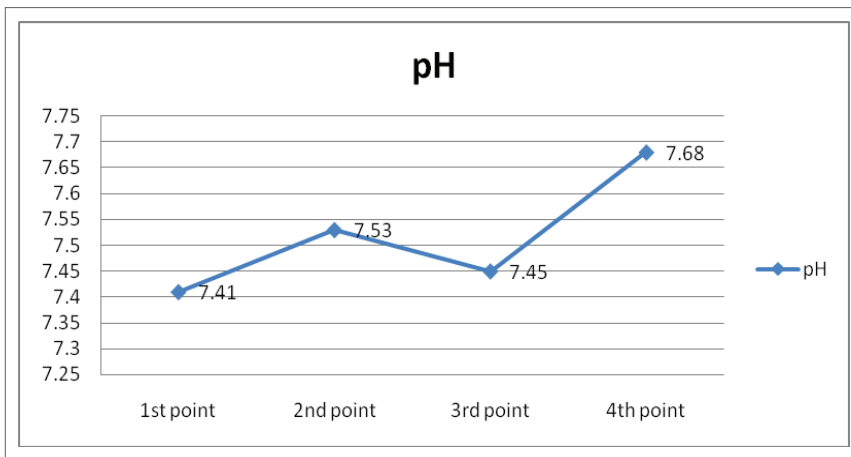

Figure 3: Graphical representation of observed values of $\mathrm{pH}$ in WWTP Batna-fesdis-Djerma site.

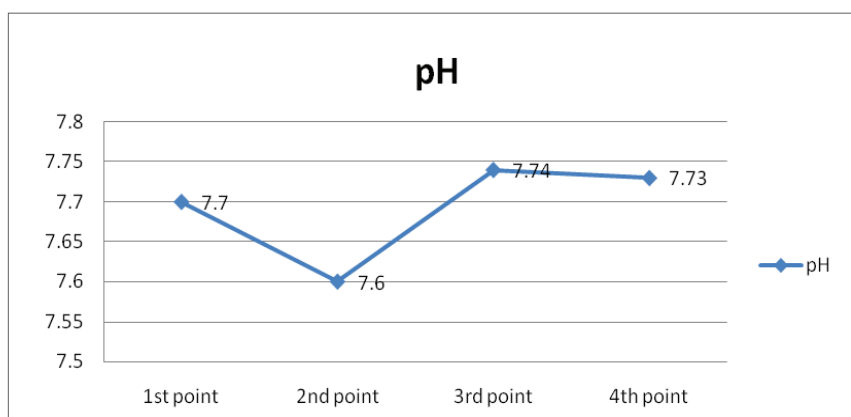

Figure 4: Graphical representation of observed values of $\mathrm{pH}$ in WWTP Timgad.

Table 1: The physico-chemical analysis of WWTP Batna sites and WWTP Timgad sites.

\begin{tabular}{|c|c|c|c|c|}
\hline $\mathbf{p H}$ & $\mathbf{1}^{\text {st }}$ point & $\mathbf{2}^{\text {nd }}$ point & $\mathbf{3}^{\text {rd }}$ point & $\mathbf{4}^{\text {th }}$ point \\
\hline $\begin{array}{l}\text { WWTP Batna- } \\
\text { fesdis-Djerma }\end{array}$ & 7.41 & 7.53 & 7.45 & 7.68 \\
\hline WWTP Timgad & 7.7 & 7.6 & 7.74 & 7.73 \\
\hline
\end{tabular}

Table 2: Heavy metal at the Batna WWTP plus the Fesdis and Djerma sites.

\begin{tabular}{|c|c|c|c|c|}
\hline Heavy metals $\mathbf{~ m g} / \mathbf{l}$ & $\mathbf{1}^{\text {st }}$ point & $\mathbf{2}^{\text {nd }}$ point & $\mathbf{3}^{\text {rd }}$ point & $\mathbf{4}^{\text {th }}$ point \\
\hline $\mathrm{Cd}$ & 0.23 & 0.19 & 0.10 & 0.08 \\
\hline $\mathrm{Pb}$ & 0.73 & 0.53 & 0.51 & 0.40 \\
\hline $\mathrm{Cr}$ & 0.60 & 0.55 & 0.39 & 0.31 \\
\hline $\mathrm{Cu}$ & 0.138 & 0.135 & 0.110 & 0.155 \\
\hline
\end{tabular}

If wastewater is used in agriculture without the necessary safety precautions, microbiological and chemical pollutants can accumulate in crops, livestock products, soil or water resources, and have serious health impacts on exposed food consumers and agricultural workers; in other words the presence of microbiological standards relating to the use of waste water such as the absence of faecal indicator bacteria, as well as the relative physico-chemical parameters to treated wastewater to assess the presence of suspended solids, nutrients and heavy metals. And control of restrictions on the practices of irrigation use of the wastewater, such as restrictions

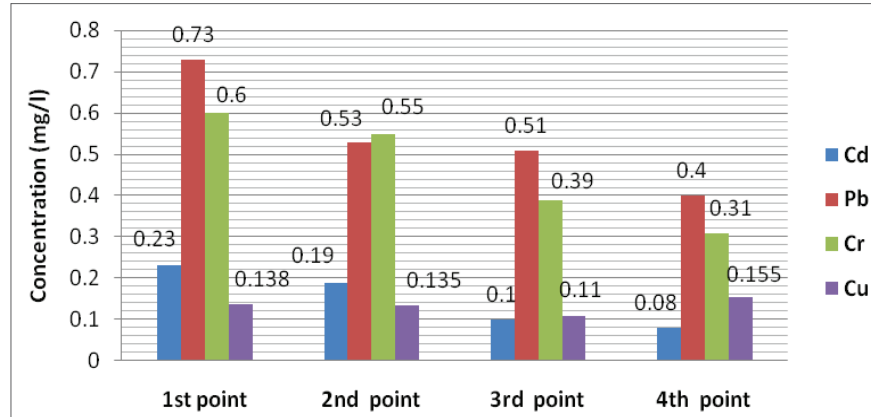

Figure 5: Spatial variation of heavy metals at the level of the WWTP Batna plus Fesdis and Djerma sites.

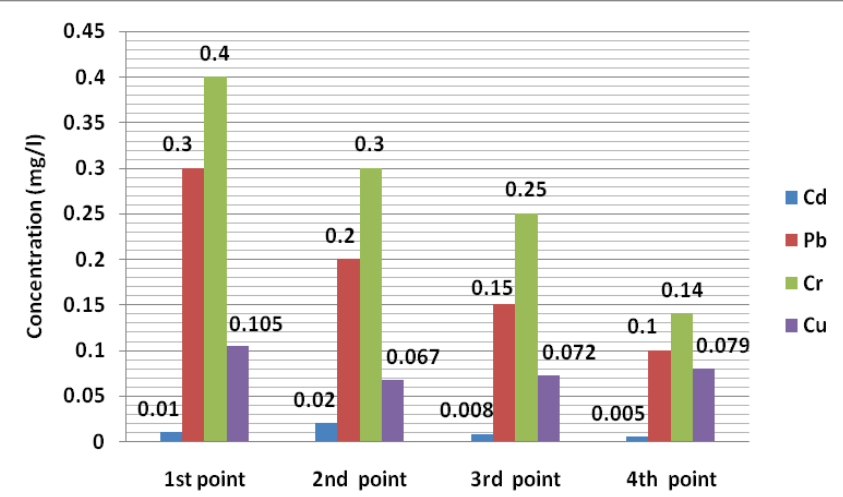

Figure 6: Spatial variation heavy metals at the Timgad- WWTP, private farm and before Koudiet Lemdouar dam.

Table 3: Guideline for safe limits of heavy metals [19].

\begin{tabular}{|c|c|c|c|c|c|}
\hline Samples & Standards & $\mathbf{C u}$ & $\mathbf{C r}$ & $\mathbf{P b}$ & $\mathbf{C d}$ \\
\hline Water ( mg/l) & WHO/FAO (2007) & 0.20 & 0.1 & 5.0 & 0.01 \\
\hline
\end{tabular}

Table 4: Heavy metals at the Timgad WWTP, private farm and before Koudiet Lemdouar dam.

\begin{tabular}{|c|c|c|c|c|}
\hline $\begin{array}{c}\text { Heavy metals } \\
\mathbf{~} \mathbf{m g} / \mathbf{l}\end{array}$ & $\mathbf{1}^{\text {st }}$ point & $\mathbf{2}^{\text {nd }}$ point & $\mathbf{3}^{\text {rd }}$ point & $\mathbf{4}^{\text {th }}$ point \\
\hline $\mathrm{Cd}$ & 0.01 & 0.02 & 0.008 & 0.005 \\
\hline $\mathrm{Pb}$ & 0.30 & 0.20 & 0.15 & 0.10 \\
\hline $\mathrm{Cr}$ & 0.40 & 0.30 & 0.25 & 0.14 \\
\hline $\mathrm{Cu}$ & 0.105 & 0.067 & 0.072 & 0.079 \\
\hline
\end{tabular}

on the use of irrigation techniques, crop control, and the protection of human exposure by ensuring clothing for farmers. However, when properly treated and used safely, wastewater is a valuable source of water and nutrients, contributing to food security and improved livelihoods [14].

The uncontrolled input of metals and metalloids into soils through irrigation with wastewater is undesirable because when they accumulate, they are very difficult to remove. This can then lead to the toxicity of plants grown in contaminated soils; uptake by vegetables, resulting in high concentrations of metals and metalloids in plant tissue that can be harmful to the health of humans or animals consuming the crops; and transport of this soil contamination to groundwater or surface water, making it unsafe to use the water for other purposes [15]. 
For the Batna-Djerma-El Maader region, the rate of heavy metals seems a little high, especially for $\mathrm{Pb}, \mathrm{Cr}, \mathrm{Cd}$ and even $\mathrm{Cu}$, compared to the standards, which requires strict monitoring and analysis for water, soil and plants. The classification of this region as an agricultural pole requires a lot of precautions to be taken in agricultural planning, knowing that the region is also the main supplier of milk for the ORLAIT (Milk factory of Batna), which endangers animal (cattle and sheep) and human health in the first place. Based on a survey along the Musi River in India, Minhas PS and Samra JS [16] detected the transfer of metal ions from wastewater to cow's milk through grasses grown in soils irrigated with wastewater and used for animal feed.

The Timgad region with its private farms surrounding the wastewater treatment plant can host good irrigation projects with treated wastewater and the development of certain crops without health and environmental risks, given the low levels of detected heavy metals. Always without ignoring the continuity of water-soilplant monitoring and analysis. As it is imperative to comply with the standards established by the World Health Organization regarding the elimination of pathogens in reused water and monitor the physicochemical and microbiological quality of these effluents after treatment and before reuse.

This promotes the classification of certain regions in the wilaya of Batna for sustainable agricultural investments with treated wastewater and encourages the zoning of high-risk and low-risk land.

In addition, project planning at the local level requires the assessment of several important underlying factors. The sustainability of wastewater use in agriculture depends on the assessment and understanding of eight important criteria: health, economic feasibility, social impact and public perception, financial feasibility, environmental impact, as well as commercial, institutional and technical feasibility [17].

\section{Conclusion}

At a global level, the reuse of wastewater is booming. Treated wastewater represents an alternative resource and the environmental and economic benefits are multiple: Protection of natural resources in times of shortage, preservation of the quality of the environment in the face of droughts, treated wastewater can be used for crop irrigation and watering of green spaces and sports fields [18].

This study has made it possible to identify the pollution of the sampling stations for the Batna WWTP, especially with regard to heavy metals in the form of trace elements, this does not ignore the work of the Batna WWTP, which requires the integration of tertiary treatment and the real cooperation of the industrial units for the recycling of their wastewater before its arrival at the waste water treatement plant (WWTP) [19].

As a result, the potential of the agricultural land in Fesdis- Djerma remains under the risk of contamination with heavy metals coming from the treated wastewater. While the recycled wastewater from Timgad can offer a lot of perspectives for agriculture by always respecting the treatment standards at the Timgad WWTP and the periodic control of the soil and plantations.

\section{References}

1. Hajjami K, Ennaji MM, Fouad S, Oubrim N, Cohen N (2013) Wastewater reuse for irrigation in morocco: Helminth eggs contamination's level of irrigated crops and sanitary risk (a case study of Settat and Soualem regions). J Bacteriol Parasitol 4: 1.
2. Alghobar MA, Suresha S (2017) Evaluation of metal accumulation in soil and tomatoes irrigated with sewage water from Mysore city, Karnataka, India. J Saudi Soc Agric Sci 16: 49-59.

3. Singh A, Sharma RK, Agrawal M, Marshall FM (2010) Risk assessment of heavy metal toxicity through contaminated vegetables from wastewater irrigated area of Varanasi, India. Tropical Ecol 51: 375387.

4. Pay D, Christopher AS, Liqa RS, Redwood M, Bahri A (2010) Irrigation with wastewater and health, assessing and mitigating risks in lowincome countries. Press University of Quebec 428.

5. FAO (2003) Irrigation with treated wastewater manuel d'utilisation. Organisation des Nations Unies pour l'Alimentation et l'Agriculture Bureau Régional pour le Proche-orient et Bureau sous-régional pour l'Afrique du Nord 68.

6. Gola D, Malik A, Shaikh ZA, Sreekrishnan TR (2016) Impact of Heavy Metal Containing Wastewater on Agricultural Soil and Produce: Relevance of Biological Treatment. Environ Process 3: 1063-1080.

7. Rodier J (2009) Water analysis: Natural water, waste water, sea water. $9^{\text {th }}$ Edition, Dunod, paris1759.

8. AFNOR (1997) Water quality and analysis methods.

9. Patterson C (1980) An alternative perspective lead pollution on the human environment: Origin, Extent and significance. In: Lead in the Human Environment: A Report. National academies, Washington DC.

10. Bouziani M (2000) Water: from scarcity to disease. Iben Khaldoun 1: 247.

11. Ameraoui S, Boutaleb A, Souiher N, Berdous D (2017) Investigation of potential accumulation and spatial distribution of heavy matals in topsoil surrounding the cement plant of Meftah (Southeastern Algiers Region, Algeria). Arab J Geosci 10: 464.

12. Bendjamaa F, Baghiani B, Amrauoi A, Amireche H (2015) Impact of wastewater from some industrial units on the Oued El Ghorzi. Sciences \& Technologie D-N 41 85-94.

13. Tamrabet $L$ (2011) Contribution to the study of wastewater reclamation in market gardening. Doctoral thesis, University Hadj Lakhdar Batna (Algeria) 146.

14. UN water Report (2017) Wastewater an unexploited resource. UN World Water Development Report.

15. Murtaza G, Ghafoor A, Qadir M, Owens G, Aziz MA, et al. (2010) Disposal and use of sewage on agricultural lands in Pakistan: $A$ review. Pedosphere 20: 23-34.

16. Minhas PS, Samra JS (2004) Wastewater Use in Peri-Urban Agriculture: Impacts and Opportunities. Karnal, Central Soil Salinity Research Institute 75.

17. WHO (2012) WHO Guidelines for the Safe Use of Wastewater, Excreta and Household Water. Geneva, Switzerland.

18. Beaupoil A, Le borgne C, Mucig C, Roux A (2010) Report on the health risks related to the reuse of treated wastewater in the aerosprinkling of green spaces. IGS-Persan 61.

19. Chauhan G, Chauhan UK (2014) Human health risk assessment of heavy metals via dietary intake of vegetables grown in wastewater irrigated area of Rewa, India. Int J Sci Res Publ 4: 1-9. 